\title{
Black Britain and the Classic Adaptation: Integrated Casting in Television Adaptations of Oliver Twist and Little Dorrit
}

The under-representation of black British histories and black British actors in British period drama has become the object of increasing public debate. ${ }^{1}$ Literary adaptations are a significant genre of British period drama, with classic novels of the nineteenth century playing an especially prominent role in British television drama production. However, the persistent absence of non-white faces in these productions has yet to receive sustained critical attention within the field of adaptation studies. ${ }^{2}$ The premise of this article is that this absence matters and that it matters in two ways. Firstly, as a popular genre of period drama at home and a key cultural export abroad, the classic adaptation plays a significant role in shaping perceptions of British heritage and culture, both past and present. Secondly, because the 'adaptation industry' (Murray) can play a powerful role in developing creative careers, structural inequalities in the type and range of opportunities it offers can have real implications for contemporary performing artists. ${ }^{3}$ In this context this article will examine the BBC 2007 adaptation of Charles Dickens's Oliver Twist (1838), in which Sophie Okonedo played the role of Nancy, and the BBC 2008 adaptation of Little Dorrit (1857), in which Freema Agyeman played the role of Tattycoram. ${ }^{4}$ In his important essay "Secrets and lies: black British histories and British historical films," published in 2002, Stephen Bourne observed that "no speaking roles have ever been given to black actors in adaptations from Dickens" ("Secrets and lies" 56). The two adaptations discussed in this article mark a significant departure from this problematic precedent. I will suggest that the casting of black British actors to play non-racially marked roles in these adaptations can be interpreted in different ways. As a representational strategy, it arguably serves to make visible the historical presence of a black diaspora in Victorian England. As a performance practice, 
however, it perhaps invites us not to see the racial identity of the actor as relevant to his or her role as a performer in a drama. Through critical reflection on the tensions between these two interpretations, this article seeks to situate classic adaptations of Victorian novels within the context of debates about representations of black British identity and history in contemporary culture.

I would like to preface the analysis which follows with some brief reflections on the relationship between the classic adaptation, period drama and televisual representations of the past. ' 'Classic' is a charged and contested term in the context of literary and cultural studies; it attributes high cultural value and claims to do so on the basis of a universal critical consensus. The term 'classic adaptation' would appear to refer transparently to the adaptation of a source text which has acquired classic status through the accumulated forces of historical, critical and institutional canonisation. However, the classic adaptation is not simply defined by its object; it can be more properly understood as a genre of literary adaptation characterised by specific representational strategies. Indeed, the classic adaptation treatment can serve to confer classic status on texts previously considered minor or marginal (examples would include the 1981 television adaptation of Evelyn Waugh's 1945 novel Brideshead Revisited). ${ }^{6}$ An attitude of deference to the source text is a defining feature of the classic adaptation but this is often combined - or even conflated - with an aesthetic of fidelity to the historical past. Indeed, the generic signifiers of classic adaptation borrow significantly from those of period drama, a genre of historical film often characterised by a preoccupation with bygone visual and material cultures. Indeed, an assumption that the appearance of historical authenticity is best achieved through a focus on coherent and consistent design with an emphasis on costumes, interiors and locations - is a defining feature of period drama. Hence the past is mediated in a number of ways in the classic adaptation. Firstly, the source 
text mediates the historical era in which it is set and / or published through its relationship to dominant literary conventions and ideological forces. Secondly, the source text is itself mediated by the process of adaptation through its relationship to the prevailing conventions of period drama, established by past production precedent and informed by contemporary historical and cultural contexts. Hence 'fidelity', whether textual or historical, is an effect of specific generic conventions within the classic adaptation. Classic adaptations arguably create an illusion of the past against which the 'authenticity' of future adaptations is judged. In this way an apparent fidelity to historical reality masks what is in truth a fidelity to the generic conventions of the classic adaptation.

Bourne has argued that 'there is ample ammunition for regarding 'whiteness' as a specific generic trait of British period films, even if it is one that their audiences unthinkingly take for granted" ("Secrets and lies" 49). There is perhaps even more ammunition for regarding 'whiteness' as a specific generic trait of the classic adaptation, given the almost universal absence of non-white actors in leading roles to date. The absence of non-white faces in classic adaptations is a product of casting conventions which both shape, and are shaped by, the generic signifiers of period drama. If the prospect of non-white faces and bodies appearing in the period context of a classic adaptation strikes some television audiences or reviewers as anomalous or inauthentic then this is arguably an effect of such conventions. In this way these conventions construct a perception of the past which denies or erases the historical existence of black and Asian British people.

\section{Victorian England and the Black Atlantic}


Contemporary black British artists have been at the forefront of those "self-consciously engaged” in acts of "(re)interpretation, (re)discovery or (re)vision concerning the Victorians [emphasis in the original]" (Heilmann and Llewellyn, 4). British Nigerian artist Yinka Shonibare is most well-known for his sculptural works using Dutch wax print fabric, a textile commonly read as a signifier of West African culture but whose production reveals the complexities and paradoxes of colonial cultural exchange: originating in Dutch Indonesia, it was manufactured in Europe and exported to African markets. However, Shonibare has also appropriated narrative representations of the Victorian gentleman in his photographic series Diary of a Victorian Dandy (1998) and Dorian Gray (2001). Diary of a Victorian Dandy is a photographic series which translates Hogarth's 1735 A Rake's Progress to a late Victorian setting in which the figure of a dissolute society gentleman is played by Shonibare himself. The figure of the fin de siècle dandy is reprised in his Dorian Gray which is as much an appropriation of Albert Lewin's 1945 film adaptation as it is of Oscar Wilde's 1890 novel; Shonibare appears in the role of Dorian as if in a series of monochrome film stills. The Scottish Ghanaian artist Maud Sulter has reclaimed the figure of Jeanne Duval (c.1820-1862), a Haitian born actress of French and African heritage who has been mythologised in art history as the lover and muse of poet Charles Baudelaire. Duval is widely assumed to be the unnamed subject of Edouard Manet's Baudelaire's Mistress, Reclining (Lady With a Fan), first exhibited in 1862, in which the dark hair and eyes of the subject's face in the right background, and a single protruding black shoe in the left foreground, emerge from the fabric of an immense white crinoline. Sulter's Jeanne Duval-A Melodrama, published by the National Galleries of Scotland in 2003, is a series of photographic self-portraits, collages and text in which Sulter re-imagines the woman immortalised as Baudelaire's 'Black Venus'. J.M.W Turner's Slave Ship, also known as Slavers Throwing Overboard the Dead and Dying - Typhoon Coming On (first exhibited in 1840), was the inspiration for Turner (1994), a long 
narrative poem published by Guyanese-born author David Dabydeen which commemorates the enslaved Africans thrown to their deaths by the crew of the Liverpool owned Zong in 1781. Dabydeen is also the author of the novel A Harlot's Progress (1999) which gives a narrative voice to the black boy depicted in William Hogarth's series of paintings and engravings of the same name. Visualising the history of people of African and Caribbean origin has been an important impulse in contemporary black British studies $;^{7}$ indeed, an image predating the Victorian period but broadly contemporary with the Regency setting of Dickens's Little Dorrit has provided a crucial reference point for a leading critical contribution to this field.

In 1817, John Thomas Smith published Vagabondiana, or Anecdotes of Mendicant Wanderers through the Streets of London, a Hogarthian collection of engravings depicting the diverse population of itinerant traders which could be encountered on the London streets, including an Italian seller of artificial silk flowers, a Jewish man whose mobility is achieved through a box with wheels and a Scottish boot lace seller who has lost both hands in battle. Also present in this vivid portrait of the street life of the English capital are individuals of African origin, including a former sailor. With a walking stick in his right hand and a high crutch supporting his left shoulder, the upturned wide-brimmed hat which he carries in his left hand may be an effect of his careful deportment or an invitation to alms giving. However, the most remarkable detail of his appearance is the tall and elaborate model of a two-masted, square-rigged ship which he carries on his head. Indeed, the ship is the "central organising symbol" (4) for Paul Gilroy's landmark study The Black Atlantic: Modernity and Double Consciousness, which seeks to "rethink modernity via the history of the black Atlantic and the African diaspora into the western hemisphere" (17). Smith's engraving is first and foremost a testament to the historical presence of black British people in the 
centuries predating the arrival of West Indian immigrants on the Empire Windrush in 1948, an event which Matthew Mead has described as a "culturally imagined moment of arrival [emphasis in original]" (139) since it has come to signify both an important new phase in the history of black people in Britain but also to obscure a much longer history. Peter Fryer famously opened his pioneering historical study, Staying Power: The History of Black People in Britain, with the observation that "[t]here were Africans in Britain before the English came here" (1), a fact brought irreverently to life in Bernardine Evaristo's 2001 verse novel The Emperor's Babe, whose protagonist is a black Londoner in AD211. Indeed, by the late eighteenth century, as a consequence of Britain's involvement in the transatlantic slave trade, thousands of people of African origin were living in London and other major port cities, including sailors who had served on British ships, former or escaped slaves from the British colonies, and those in flight from America, including some who had fought on the Loyalist side in the Revolutionary Wars. However, the singular self-fashioning depicted in Smith's engraving also signifies the ways in which black British people have, throughout the centuries, been required to account for their presence by a dominant culture which equates Britishness with whiteness. In his essay "Negotiating the Ship on the Head: Black British Fiction," Kwame Dawes identifies the man as Joseph Johnson and suggests that:

He literally wore the badge of his migrant status - his sense of alienation and difference - on his head. . It would mean everything to him and to those he encountered, for it was that vessel that explained his presence in England as a Black man, and that, at the same time, proclaimed his alienness, his marginalisation and migrant status. (255) 
The construction of black British people as alien, marginal or migrant is a product of racialised discourses of nation and Empire. As Gilroy writes: "black history and culture are perceived, like black settlers themselves, as an illegitimate intrusion into a vision of authentic British national life that, prior to their arrival, was as stable and as peaceful as it was ethnically undifferentiated [emphasis added]" (7).

When the British film-maker Andrea Arnold cast black British actors Solomon Glave and James Howson to play the parts of the younger and older Heathcliff in her 2011 film adaptation of Emily Brontë's 1847 novel Wuthering Heights she made a significant and important departure from classic adaptation casting convention. In Brontë's novel Heathcliff is variously described as a "little Lascar, or an American or Spanish Castaway" (48) and a "gypsy" (48), a term which Susan Meyer describes as "the generic designation for a darkcomplexioned alien in England" (97); in other words, he is explicitly, if ambiguously, racially marked. However, from Laurence Oliver in William Wyler's 1939 film, to Ralph Fiennes in Peter Kosminsky's 1992 adaptation and Tom Hardy in Coky Giedroyc's 2009 television production, the casting of Heathcliff in film and television adaptations of Wuthering Heights has defied this textual evidence; in this way, while Arnold's adaptation, in the words of one contemporary reviewer, "tear[s] up the rule book for adapting period novels" (Raphael 36) it does so in an act of fidelity to a significant detail of the source text which has arguably been obscured by the casting conventions of the classic adaptation genre. By contrast, the characters of Nancy in Oliver Twist and Tattycoram in Little Dorrit are not explicitly racially marked in Dickens's novels. Moreover, there is little evidence to suggest that these productions intended to foreground the experience of black British subjects by casting black British actors in these roles; no direct reference to their racial identity is made in these adaptations. In other words, the 2007 Oliver Twist and the 2008 Little Dorrit would seem to 
represent rare examples of integrated casting in which an actor is cast on the meritocratic basis of his or her talent and ability alone. In her 2009 article "To Notice or Not to Notice: Shakespeare, Black Actors and Performance Reviews," Ayanna Thompson explores the ways in which, in different production contexts, an audience can be invited "to see and notice blackness" or "not to see or notice blackness [emphasis added]" (4). In the former, the perceived racial identity of the actor or actors is mobilised to signify specific meanings in a particular dramatic context; by contrast, the latter is made possible by the practice of integrated casting which implicitly asks the audience not to attribute any specific meaning to the perceived racial identity of individual performers. In what follows I intend first to consider the relationship between the casting of black British actors in these particular roles and the racialised and colonial subtexts of the source texts. Through close textual analysis I aim to suggest the coded or even inadvertent ways in which the perceived racial identity of the two actors - the only non-white performers to be given significant speaking roles in each production - might be seen to signify historical meanings to do with black British history. By contrast, I then intend to situate these productions in the context of debates about integrated casting with a view to beginning to articulate and explore the complex issues which this progressive strategy makes explicit.

\section{"Illegitimate intrusions": Nancy and Tattycoram}

Oliver Twist is one of Dickens's most widely adapted novels and one whose explicit racial marking of its Jewish villain, Fagin, has caused offence from the date of its first publication. David Lean's 1948 adaptation has achieved classic status in the adaptation canon but caused rioting in post-war Berlin because of its perceived anti-semitism when it was first screened there. ${ }^{8}$ This novel presents significant challenges for those adapting it for the screen: namely, how to acknowledge the reality of the anti-semitism of the period without becoming 
complicit in anti-semitic representational strategies. In this context, strict fidelity is unlikely to find an approving audience; few adaptations reproduce the scene in Dickens's novel in which a "pale and agitated" (257) Oliver is woken from a drowsy reverie to cry "the Jew! the Jew!"' (257) when Fagin intrudes on his Chertsey idyll. Carol Reed's 1968 adaptation of Lionel Bart's stage musical Oliver! is undoubtedly the adaptation which has had the most abiding impact on the popular imagination. As Joss Marsh and Carrie Sickmann have argued, the phenomenal success of the original production did not only "turn out to be a starmaking machine, a star British export and a populist post-modern tourist experience" but also a pivotal "spur to the adaptation industry." "Moreover, it is a film which powerfully mobilises the cultural codes of whiteness in its deployment of the fair skin, fine features and blond hair of its delicate child star Mark Lester. Richard Dyer has suggested that "[i]n Western tradition, white is beautiful because it is the colour of virtue" (72) and that the "media of light" (83) (photography and cinema) have played a significant role in reinforcing this equation though their "privileging [of] white people" (83). Such racialised registers of representation are in some way mitigated in the BBC 2007 television adaptation of Oliver Twist, which presents an Oliver (played by William Miller) who more closely resembles Jack Wild's 1968 Artful Dodger than Lester's Twist. A co-production between the BBC and WGBH Boston, part of the CBS network, this adaptation was first broadcast in the UK in five episodes in December 2007. The screenplay, written by Sarah Phelps, a former scriptwriter for the British soap opera Eastenders, poignantly counterpoints Oliver's eventual reunion with his birth family with the break-up of the Artful Dodger's adoptive family; he cries over the discovery of Nancy's brutalised body and fails to save Fagin from a public hanging. Michael Phipps's Ivor Novello-winning music further underlines the theatricality of this production with a score in which the accordion, fiddle and ukelele offer the impression of live accompaniment, with touches of klezmer evoked by the occasional clarinet. Cheerful and 
purposeful anachronisms pepper a dynamic, action-driven script: for example, Dodger welcomes Oliver to Fagin's table by encouraging him to "fill your boots." This is a Twist for a contemporary audience and one which brings the imperatives of intelligent popular entertainment, as much as literary deference, to its source text. Sophie Okonedo, who plays the role of Nancy, is a versatile and respected British theatre, film and television actor who was nominated for an Oscar for her role in Hotel Rwanda (2004) and for a BAFTA for her leading role in the biopic Mrs Mandela (2010). Her credits range from roles in ensemble casts in British film and television drama to leading roles in international film productions, including Skin (2008) in which she played a woman born to a white family in South Africa but categorised as mixed race by the apartheid regime.

While Little Dorrit has been much less frequently adapted, Christine Edzard's 1988 film version has proved a key text in debates about the classic adaptation and its relation both to heritage and to historical realism. Edzard's three hour film, consisting of two feature length parts - "Nobody's Fault" and "Little Dorrit's Story" - was produced for theatrical release and an art house audience. For many it marked a turning point in literary adaptation towards a greater historical realism and textual fidelity, but for others, most notably Raphael Samuel, it was seen to establish the new generic signifiers of the heritage film which have proved so contentious. Samuel famously denounced Edzard's Little Dorrit in two essays published in his 1994 collection Theatres of Memory; in the course of his analysis he diagnoses the defining sleight of hand by which the classic adaptation operates when he writes that "truth to period and fidelity to text had been treated as equivalents" (“Who Calls So Loud?"” 417). Moreover, he argues that, as a manifestation of what he called "Docklands Dickens", Edzard's Little Dorrit was complicit in the very ideology it sought to contest, furnishing audiences with a "showcase of period delights" (“"Who Calls So Loud?”" 423) in place of 
social critique. In the context of this article, Edzard's Little Dorrit is also significant for a rare instance of integrated casting. The character of Pancks is played by respected Indianborn British actor Roshan Seth, whose face would have been familiar to contemporary art house cinema audiences from his roles in Richard Attenbrough's 1982 biopic Gandhi and David Lean's 1984 adaptation of E.M Forster's A Passage to India. The 2008 Little Dorrit was a co-production between the BBC and WGBH Boston and was seen by many as an attempt to emulate the success of the highly acclaimed 2005 adaptation of Bleak House. Retaining the complex plot, sombre mood and melancholy pathos of the source text, its adoption of the 'soap opera' broadcast format pioneered by Bleak House was perhaps not as fitting a match between form and content. Freema Agymena, who plays Tattycoram, is best known for her role as Martha Jones (2006-2010) in the British science fiction series Doctor Who; the first black British actor to be cast in the role of the Doctor's companion, she appeared in a series already noted for its commitment to integrated casting under the creative direction of showrunner, Russell T. Davies.

Nancy and Tattycoram are both relatively minor characters in Dickens's Oliver Twist and Little Dorrit respectively. Nancy's elevation to a signature role in stage, film and television adaptations has been the object of critical reflection. Susan Zemka suggests that Nancy's prominence owes much to the attention her violent death attracted in Dickens's public readings of his novel and its subsequent stage adaptations. ${ }^{10}$ Moreover, Benjamin Poore has argued that the desire to discover a "complex yet consistent interiority" has been a recurring motif, despite the fact that "an individuated, rounded, psychologically realized 'character' called Nancy"11 is notably absent from Dickens's novel. By contrast, Tattycoram's character was omitted entirely in Edzard's adaptation of Little Dorrit. However, close analysis of these characters roles in these novels, and their 2007 and 2008 adaptations, reveals affinities which 
are striking, especially when considered in the context of Paul Gilroy's observation that "black history and culture are perceived ... [as] illegitimate intrusion[s] [emphasis added]" (7).

In Oliver Twist and Little Dorrit Nancy and Tattycoram are both characters who have suffered childhood abandonment, who lack a legitimate familial origin and who are depicted as suffering passionate fits of rage. In Dickens's Oliver Twist, Oliver's institutionalised beginnings are the focus of narrative sentiment and melodramatic restitution, but Nancy's childhood of desperate and unrelieved need is never compensated. In her own words, she has known only "cold and hunger, and riot and drunkenness . . . from [the] cradle" (302) and yet her testimony of infant destitution is more often read as a confession of moral character than an indictment of societal neglect; the "something worse than all" (302) to which she alludes is commonly read as evidence of her induction into prostitution rather than subjection to sexual abuse. In the 2007 Oliver Twist, Nancy's affinity with Oliver as an abandoned child is emphasised in an inserted scene in which she shares her motherless state with him, albeit admitting no desire to know the identity of her mother, whereas this hope is Oliver's dearest wish. This affinity suggests a shared condition - that of illegitimacy - but where Oliver's class status ultimately overwrites his illicit origin, Nancy has no purchase on respectable society. In Dickens's Little Dorrit, the “"oddity” (32) of Tattycoram's name is remarked upon by Arthur Clennam and she rages against the way that others exercise the "“right to name her like a dog or a cat"' (343). Taken from the Foundling Hospital to serve as a maid to the daughter of her benefactors, her parish name, "Harriet Beadle," is diminished to Tatty and compounded with the name of the Hospital's famous founder, Thomas Coram: her “"arbitrary"” (32) name only highlights her stigmatising lack of legitimacy. Stolen away like Oliver, her new protector, Miss Wade, competes for her ownership with her former master, 
Mr Meagles, by describing Tattycoram as "a foil to his pretty daughter, a slave to her pleasant wilfulness, and a toy in the house showing the goodness of the family" (348). Exchanged and pursued like a disputed object of property, arbitrarily named by her owners and subject to a kind of indentured servitude, Tattycoram is effectively a "slave [to] the state" (Taylor 329), to use a phrase employed by John Brownlow, himself a foundling and author of a number of histories of the Foundling Hospital. In the 2008 adaptation, Tattycoram's indentured status is accentuated by the location of her first passionate outburst. In the novel this takes place in a private, domestic space but in the adaptation it is transferred to the public docks of Marseilles, a charged location in the context of the history of the triangular trade; the runaway is discovered hiding amidst a ship's cargo in a brick lined, low ceilinged cellar, a place of confinement somewhat echoed in Oliver Twist (2007), where Nancy's ghost drives Sikes to take his own life in the sewers of London.

While neither Nancy nor Tattycoram are identified as non-white in Dickens's novels, the racialised symbolism of whiteness - and its antonyms - is mobilised in their characterisation. In Oliver Twist Nancy and her companion Bet are initially introduced as women with "a great deal of colour in their faces" (62) and the reader is invited to speculate what this might signify about their moral character. As Dyer has argued, whiteness has come to be equated with "purity, spirituality, transcendence, cleanliness, virtue, simplicity, chastity" (72) in Western traditions of representation. Whether flushed (by exertion, intoxication or arousal) or darkened (through exposure or dirt), Nancy and Bet's complexion suggests a compromised relationship to the "colour of virtue" (Dyer 72). Indeed, Nancy's awakening conscience is signified by a 'whitening' of her appearance as she turns "deadly white" (110), "quite colourless" (115), "white and agitated" (147) and "pale and reduced" (287), to the point that 
Fagin exclaims “"Why Nance ... how pale you are!” (295). In Dickens’s Little Dorrit, Tattycoram's "defective" (33) temper is implicitly attributed to a problematic heredity, as Meagles infers more than once: "'Heaven knows what her mother's story must have been”" (343). Moreover, this heredity is manifested in her striking appearance; she is described as a "handsome girl with lustrous dark hair and eyes" (31), "rich black hair" (40) and "full red lips together" (214). In her temper Tatty is "sullen" (40), "vehement" (343), "passionate and proud" (340); she "sob[s]" (40), "rage[s]" (40), "battles" (42) and "br[eaks] out violently" (342). Taylor compares the representation of Tattycoram in Little Dorrit with Oliver in Oliver Twist, suggesting that "the innocence of Oliver is replaced by the torments of a voluptuous adolescent girl whose overt sexuality is tacitly linked to her racial ambiguity [emphasis added]" (349). Temper is the vehicle by which she manifests a perceived moral failing which is charged with colonial meanings: ingratitude. As H.L Malchow has written in Gothic Images of Race in Nineteenth-Century Britain:

Those who are the receivers of liberation, protection, or education in the Christian virtues of patience and forbearance are expected to repay benevolent condescension with self-abasing thankfulness and loyalty. The cardinal sin in this system is "ingratitude," a failing ... that the Victorians were later quick to ascribe to sepoy troops and Jamaican freed slaves. (31)

In her book Rule Britannia: Women, Empire, and Victorian Writing (1995), Deirdre David suggests that from Oliver Twist, through Little Nell in The Old Curiosity Shop to Jo the crossing sweeper in Bleak House, Dickens juxtaposes the suffering or abused child with signifiers of Empire, implying a contempt both for the hypocrisies of philanthropy and the racial 'others' who are its object. The racial and colonial oppositions and hierarchies suggested in this motif are complicated and perhaps challenged when the suffering or abused child is inferred to be a child of the black Atlantic, as might be suggested by the casting of an 
actor of African heritage in the roles of Nancy and Tattycoram. Taylor argues that illegitimacy is a:

slippery yet fundamental economic, legal, and symbolic category [which] underpinned and unsettled a range of social discourses and their legitimizing frames. Such discourses related of course to the many forms and meanings of family, marriage, and kinship. They necessarily embodied fluctuating ideas about genealogy, hybridity, "race," and national identity; moreover, they articulated complex forms of psychic and social inheritance. (293)

Indeed, this complex web of anxieties might find a particular destination in the child born out of wedlock who is also mixed race.

While neither Nancy nor Tattycoram are explicitly racially marked in either of Dickens's novels, the discourses of illegitimacy which do mark them are arguably implicated in colonial and racial subtexts. By depicting Nancy and Tattycoram as British born black subjects the BBC adaptations of Oliver Twist (2007) and Little Dorrit (2008) are reflecting the historical reality of a black British presence in Victorian England. This fact is underlined in the 2007 Oliver Twist where the presence of men, women and children of African heritage in London is established from the point of Oliver's arrival in the city; from the working men and women, carrying the tools of their trade, who pass him in the street to the boy members of Fagin's crew. Thus far, I have read the perceived race of the actors playing Nancy and Tattycoram as carrying textual or historical meanings but in doing so I have arguably placed a 'ship on the head' (Dawes) of these two characters, requiring them to bear a representational burden that a white actor would rarely be expected to tolerate. ${ }^{12}$ White actors are no less 'raced' than black actors, of course, but the historical invisibility and presumed universality of whiteness has served to obscure this. As Dyer puts it: "There is no 
more powerful position than that of being 'just' human. The claim to power is the claim to speak for the commonality of humanity. Raced people can't do that - they can only speak for their race" (2). However, these adaptations arguably invite such readings because Okonedo and Agyeman are the only non-white actors in speaking roles in an otherwise exclusively white cast; I wish to conclude by situating Oliver Twist (2007) and Little Dorrit (2008) in the context of debates about integrated casting.

\section{Integrated Casting in Oliver Twist and Little Dorrit}

In a fascinating aside to his observations on the absence of black British actors in adaptations of Dickens, Bourne records that:

a breakthrough was almost made by the director Carol Reed in 1968 when he filmed Lionel Bart's musical Oliver!, based on Oliver Twist. Robert F. Moss reports that when casting Nancy, 'Reed's first choice for the part was Shirley Bassey but Columbia [Studios] vetoed her because it was felt that a black Nancy would alienate filmgoers in the American South.' (“Secrets and lies” 56)

To date, scholarship on the theory and practice of integrated casting has tended to focus on theatre, with a special emphasis on the history of the American stage (and productions of Shakespeare); the above anecdote goes some way to explaining why this is so. Integrated casting was pioneered by Joseph Papp's New York Shakespeare Festival in the 1950s and has a close relationship to the struggle to desegregate the American theatres and to redress the offensive legacy of black face performance. Integrated casting strategies have been extended from the American stage to film and television adaptations of Shakespeare's plays, with the casting of Denzel Washington as Don Pedro in Kenneth Branagh's film adaptation Much Ado 
About Nothing (1993) marking a significant turning point. By contrast, it is striking that period adaptations of classic novels continue to be an almost exclusively white preserve.

The underlying principle of integrated casting is simple and meritocratic; namely that, as Thompson puts it, "neither the race nor the ethnicity of an actor should prevent her or him from playing a role as long as she or he was the best actor available" ("Practicing a Theory / Theorizing a Practice" 6). In practice, this means the casting of non-white actors in roles that are not racially marked as being other than white; white actors have historically experienced no difficulty in being cast in roles which are racially marked as other than white, such as Shakespeare's Cleopatra or Othello. ${ }^{13}$ The variety of terms used within industry contexts to denote this practice - including 'colourblind' and 'nontraditional' - reveal both the complexity of this strategy and its fraught relationship with the problematic category of race. Quite apart from its use of visual impairment as a metaphor (albeit a nominally virtuous one), the term 'colourblind' implicitly conflates race and ethnicity; moreover, it relies on visible signifiers which are arguably complicit in visual regimes of race and racism. I have employed 'black British' as a political category in my descriptions of Okonedo and Agyeman's perceived race; this category accounts for the way in which they are constructed as other than white by dominant British culture but arguably obscures Okonedo's Nigerian Jewish heritage and Agyeman's Iranian Ghanaian heritage. The term 'nontraditional' is similarly mortgaged to conservative ideas about theatre history. In his article "The Welcome Table: Casting for an Integrated Society," Daniel Banks notes that the African Grove Theatre was founded in 1821 in New York, only 51 years after Thomas Kean's 1750 Richard III, which is conventionally seen as the first production of a Shakespeare play in the Unites States; he points out that the use of the term 'non-traditional' to describe the casting of a non- 
white actors in Shakespearean roles which are not racially marked effectively erases this long history.

Moreover, in practice integrated casting can take a variety of different and even contradictory forms; this is perhaps inevitable given the complex and contested nature of 'race', the category to which it is necessarily mortgaged. Roles where questions of race or ethnicity are central to the dramatic action are often considered exempt from integrated casting strategies, including the very few roles in the classical repertoire which have become the preserve of non-white actors (such as Othello). Moreover, the practice of casting of non-white actors in roles which are not traditionally seen as racially marked can be strategic and motivated, serving to foreground issues of cultural or racial difference in ways which are far from 'colourblind.' Thompson illustrates this variety with reference to two productions staged by the same company in a single season; as part of its Complete Works Festival in 2006-7 the Royal Shakespeare Company staged The Winter's Tale and Pericles at the Swan Theatre in Stratford and then in residency at Davidson College, USA. The company was unusually integrated by British theatre standards (ten of the twenty five members of the company were non-white) ${ }^{14}$ however, this integrated cast was employed to very different effects in each production. In The Winter's Tale the perceived race of the actor played no part in the dramatic action; in Pericles, by contrast, the action was transferred to an unnamed country in Africa and actors were cast along racial lines. As Thompson puts it:

In the former, the audience was asked not to see or notice blackness. More than an empty signifier, blackness - if noticed at all by the audience - became a false signifier. It did NOT provide any semantic, performative, or interpretative lenses that enhanced, impacted, or even informed the production. In the latter, on the other hand, the audience was asked to see and notice blackness. More than a signifier of mere 
racial difference, blackness in Pericles became a signifier of geographical, national, cultural, and racial import [capitalisation in original, emphasis added]. ("To Notice or Not to Notice" 4)

Returning to Oliver Twist (2007) and Little Dorrit (2008) I would suggest that while these productions appear to invite us "not to see and notice [emphasis added]" (Thompson, "To Notice or Not to Notice" 4) the perceived race of the actors playing Nancy and Tattycoram, they nevertheless implicitly assume that the audience will "see and notice" racial difference in specific ways. Okonedo and Agyeman are cast in roles which are not racially marked within the dramatic action of the adapted screenplay; the characters within this fictionalised world are not depicted as 'seeing and noticing' the racial identity of Nancy and Tattycoram and the production arguably invites the viewing audience to follow their lead. In this way these adaptations embody the meritocratic spirit of integrated casting and provide important precedents for future productions. However, the casting of black actors in these particular roles - as characters of uncertain birth - is potentially problematic. It would seem that while these productions do not explicitly address the experience of black British subjects in the dramatic action (including the experience of racism) they nevertheless cast non-white actors in roles which a mainstream white audience might find historically plausible: that is, as figures on the margins of legitimate society. Nancy and Tattycoram both live a precarious existence, whether dependent on paternalist charity or the criminal economy. The marriage plot, so central to the Victorian classic realist narrative, is beyond the reach of these women; they have no place in the networks of family name and inheritance which ensure personal identity. Hence, the casting of black British actors in these roles could inadvertently confirm an impression that the origins of black British subjects must in some way be questionable, if not implicated in transgression or shame. It is as if this casting strategy produces the very 
question which it attempts to pre-empt: the question of the legitimacy of a black presence in nineteenth century England and, moreover, of a black presence in the period drama genre.

To conclude, in his book Maps of Englishness: Writing Identity in the Culture of

Colonialism, Simon Gikandi diagnoses "a remarkable tendency to dissociate blackness from Englishness, a separation that has presented an intellectual and political challenge to the crown's black subjects as they seek their place in the postimperial nation" (51). This article has sought to articulate some questions about performance, race and representation in classic adaptations of Victorian novels. Film and television adaptations of narratives set in the nineteenth century period play a powerful role in shaping popular perceptions about British identity and heritage and can play a crucial role in either contesting or reinforcing the construction of a black British presence as an "illegitimate intrusion" (Gilroy 7). I have suggested that the performance and production codes which prevail in classic adaptations implicitly rely on assumptions about historical and literary fidelity which demand close scrutiny; a fidelity to period details is conflated with historical realism, obscuring the extent to which ideas to do with historical authenticity are ideologically constructed and historically specific. As Samuel wryly observes of Edzard's Little Dorrit, “the film's preoccupation with period effects is singularly at variance with Dickens himself, who was notoriously cavalier in his treatment of history"( "Who Calls So Loud?" 409). The criterion of fidelity lends a spurious authority to the depiction of the past created by the classic adaptation, which presents the British Isles as exclusively populated by white men and women. Moreover, it creates a significant branch of often prestigious cultural production in which the exclusion of non-white people is naturalised. 'Seeing and noticing' the perceived race of an actor can be discriminatory in some contexts but affirming in others. Writing in an American context, 
Ayanna Thompson observes that "[i]t is all too easy to foreclose the necessary dialogues about the relationship among identity, performance, and race when they are so painful, destabilising, and even potentially dangerous" ("Practicing a Theory / Theorizing a Practice" 16). However, failing to see and notice the absence of non-white actors in classic adaptations on British television screens is equally problematic; this article has suggested that it is important to make this absence visible and to consider what it signifies. The 2007 Oliver Twist and 2008 Little Dorrit represent significant departures from prevailing casting conventions and, as such, are worthy of notice. It remains to be seen whether they will come to be regarded as providing pivotal precedents for a more integrated approach to the classic adaptation, or whether they will remain isolated exceptions in a genre which continues to depict the black British presence as illegitimate and intrusive.

\footnotetext{
${ }^{1}$ This issue has been brought to the attention of the national UK media by leading black British performers, including Paterson Joseph ("Why Wuthering Heights Gives Me Hope”, The Guardian, 11 November 2011; "Why Were the BAFTAs So White?", The Guardian, 16 May 2014) and David Harewood ("For me, Homeland has been a second birth," The Observer, $9^{\text {th }}$ December 2012; "Homeland Star David Harewood Bemoans Lack of Black Roles in UK," The Independent, 24 July 2012). The under-representation of black, Asian and minority ethnic people in the British television industry was the focus of Lenny Henry's 2014 BAFTA Television Lecture.

${ }^{2}$ For histories of black and Asian British people on screen see Stephen Bourne, Black in the British Frame (London: Continuum, 2001), Sarita Malik, Representing Black Britain: Black and Asian Images on Television (London: Sage, 2002) and Isaac Julien's two part documentary film Black and White in Colour (BBC, 1992).

${ }^{3}$ Leading black British and British Asian actors have turned to the US television industry for opportunities denied them in the UK, including Idris Elba (The Wire, 2002-4), David Harewood (Homeland 2011-12), Marianne Jean-Baptiste (Without a Trace, 2002-9) and Archie Panjabi (The Good Wife, 2009-2014).
} 
${ }^{4}$ While the adaptations examined in this article have prompted a focus on African and Caribbean black British histories, the framework of analysis explored here is equally relevant to the representation of South Asian and East Asian heritage. For example, in the 2013 BBC adaptation of Dickens's unfinished novel The Mystery of Edwin Drood the South Asian heritage of the Anglo-Indian siblings, Helena and Neville Landless, was affirmed by the casting of Amber Rose Revah and Sacha Dhawan in these roles. By contrast, the popular stage musical Drood (book, music and lyrics, Rupert Holmes), which premiered at the New York Shakespeare Festival in 1985, mobilises Orientalist motifs in its self-conscious pastiche of music hall and pantomime traditions.

${ }^{5}$ Key critical interventions in this field would include: Sarah Cardwell, Adaptation Revisited: Television and the Classic Novel (Manchester: Manchester University Press, 2002); Robert Giddings and Keith Selby, The Classic Serial on Television and Radio (London: Palgrave Macmillan, 2001); Robert Giddings and Erica Sheen (eds), The Classic Novel: From Page to Screen (Manchester: Manchester University Press, 2000); Paul Kerr, "Classic Serials - To Be Continued" Screen 23:1 (1982): 6-19.

${ }^{6}$ See Thomas Leitch, “Traditions of Quality," Film Adaptation and its Discontents: From Gone With the Wind to The Passion of the Christ (Baltimore: Johns Hopkins University Press, 2007): 151-178.

${ }^{7}$ At the time of writing two major exhibitions are exploring historical images of black British people: Black Chronicles II (curated by Autograph ABP and supported by the Heritage Lottery Fund, Rivington Place, London, 2014) and Re-imagine: Black Women in Britain (the inaugural exhibition of the Black Cultural Archives, London, 2014).

${ }^{8}$ See Juliet John, “Fagin, the Holocaust and Mass Culture; or, Oliver Twist on Screen,” Dickens Adapted, ed. John Glavin (Farnham, Surrey: Ashgate, 2012): 205-223.

${ }^{9}$ Joss Marsh and Carrie Sickmann, "The Oliver! Phenomenon; Or, 'Please, sir, we want more and more!"” Dickens and Modernity, ed. Juliet John (Cambridge: D.S Brewer, 2012) 151.

${ }^{10}$ See Sue Zemka, “The Death of Nancy 'Sikes', 1838-1912,” Representations, 110:1 (Spring 2010): 29-57.

${ }^{11}$ Benjamin Poore, “'I have been true to you, upon my guilty soul I have!': Negotiating Nancy, 'hyperauthenticity' and 'hyperfidelity' in the 2007 BBC adaptation of Oliver Twist," Journal of Adaptation in Film \& Performance 3:2 (2010) 160.

${ }^{12}$ See Kobena Mercer, "Black Art and The Burden of Representation,” Third Text 4:10 (1990) 61-78.

${ }^{13}$ For a critical discussion of the "white monopoly" on the role of Cleopatra see Celia R. Daileader, "The Cleopatra Complex: White Actresses on the Interracial "Classic" Stage, Colorblind Shakespeare: New Perspectives on Race and Performance, ed. Ayanna Thompson (New York; London: Routledge, 2006) 205-220. 
${ }^{14}$ In "The Shakespearean Glass Ceiling: the State of Colorblind Casting in Contemporary British Theatre," Jami Rogers offers a survey which demonstrates that the perception that 'colourblind' casting has become the norm is not supported by evidence. Shakespeare Bulletin 31:3 (Fall 2013): 405-430.

\section{References}

Banks, Daniel. “The Welcome Table: Casting for an Integrated Society.” Theatre Topics 23:1 (March 2013): 1-18.

Black and White in Colour. Dir. Isaac Julien. BBC. 1992.

Bourne, Stephen. "Secrets and lies: black British histories and British historical films." British Historical Cinema: The history, heritage and costume film. Ed. Claire Monk and Amy Sergeant. London and New York: Routledge, 2002: 47-65.

Bourne, Stephen. Black in the British Frame. London: Continuum, 2001.

Brontë, Emily. Wuthering Heights (1847). Oxford: Oxford UP, 1982.

Cardwell, Sarah. Adaptation Revisited: Television and the Classic Novel. Manchester: Manchester University Press, 2002.

Dabydeen, David. A Harlot's Progress. London: Vintage,1999

Dabydeen, David. Turner. London: Cape, 1994.

Daileader, Celia R. "The Cleopatra Complex: White Actresses on the Interracial "Classic" Stage." Colorblind Shakespeare: New Perspectives on Race and Performance. Ed. Ayanna Thompson. New York; London: Routledge, 2006: 205-220.

David, Deirdre, Rule Britannia: Women, Empire, and Victorian Writing. New York: Cornell UP, 1995. 
Dawes, Kwame. "Negotiating the Ship on the Head: Black British Fiction.” Black British Writing. Ed. R. Victoria Arana and Lauri Ramey. London: Palgrave Macmillan, 2004: 255-281.

Dickens, Charles. Little Dorrit (1857). London: Penguin, 1988.

Dickens, Charles. Oliver Twist (1838). London Vintage, 2007.

Dyer, Richard. White. London: Routledge, 1997.

Evaristo, Bernardine. The Emperor's Babe. London: Penguin, 2001.

Fryer, Peter. Staying Power: The History of Black People in Britain. London: Pluto Press, 2010.

Giddings, Robert and Erica Sheen (eds). The Classic Novel: From Page to Screen. Manchester: Manchester University Press, 2000.

Giddings, Robert and Keith Selby. The Classic Serial on Television and Radio. London: Palgrave Macmillan, 2001.

Gikandi, Simon. Maps of Englishness: Writing Identity in the Culture of Colonialism. New York: Columbia UP, 1996.

Gilroy, Paul. The Black Atlantic: Modernity and Double Consciousness. London and New York: Verso, 1993

Harewood, David. "For me, Homeland has been a second birth." The Observer. 9 December 2012. 10 July 2014 <http://www.theguardian.com/culture/2012/dec/09/david-harewood-interviewhomeland>

Harewood, David. "Homeland Star David Harewood Bemoans Lack of Black Roles in UK." The Independent. 24 July 2012. 10 July 2014. <http://www.independent.co.uk/artsentertainment/tv/news/homeland-star-david-harewood-bemoans-lack-of-black-rolesin-uk-7966293.html> 
Heilmann, Ann and Mark Llewellyn. Neo-Victorianism: the Victorians in the twenty-first century, 1999-2009. Basingstoke: Macmillan Palgrave, 2010.

John, Juliet. "Fagin, the Holocaust and Mass Culture; or, Oliver Twist on Screen." Dickens Adapted. Ed. John Glavin. Farnham, Surrey: Ashgate, 2012: 205-223.

Joseph, Paterson. "Why Were the BAFTAs So White?" The Guardian. 16 May 2014. 10 July 2014. <http://www.theguardian.com/commentisfree/2013/may/16/baftas-blackactors-tv>

Joseph, Paterson. "Why Wuthering Heights Gives Me Hope". The Guardian. 11 November 2011. 3 December 2013.

<http://www.theguardian.com/commentisfree/2011/nov/11/wuthering-heights-blackactors>

Kerr, Paul. “Classic Serials - To Be Continued.” Screen 23:1 (1982): 6-19.

Leitch, Thomas. Film Adaptation and its Discontents: From Gone With the Wind to The Passion of the Christ. Baltimore: Johns Hopkins University Press, 2007.

Little Dorrit. Dir. Adam Smith, Dearbhla Walsh and Diarmuid Lawrence. BBC / WGBH Boston. 2008

Malchow, H.L. Gothic Images of Race in Nineteenth-Century Britain. Stanford, California: Stanford UP, 1996.

Malik, Sarita. Representing Black Britain: Black and Asian Images on Television. London: Sage, 2002.

Marsh, Joss and Carrie Sickmann. "The Oliver! Phenomenon; Or, 'Please, sir, we want more and more!'” Dickens and Modernity. Ed. Juliet John. Cambridge: D.S Brewer, 2012: 150-170.

Mead, Matthew. "Empire Windrush: The cultural memory of an imaginary arrival." Journal of Postcolonial Writing 45:2 (2009) 137-149. 
Mercer, Kobena. "Black Art and The Burden of Representation," Third Text 4:10 (1990) 6178.

Meyer, Susan. Imperialism at Home: Race and Victorian Women's Fiction. New York: Cornell UP, 1996.

Murray, Simone. The Adaptation Industry: The Cultural Economy of Contemporary Literary Adaptation. New York and London: Routledge, 2012.

Oliver Twist. Dir. Coky Giedroyc. BBC / WGBH Boston. 2007.

Poore, Benjamin. “'I have been true to you, upon my guilty soul I have!': Negotiating Nancy, 'hyperauthenticity' and 'hyperfidelity' in the 2007 BBC adaptation of Oliver Twist," Journal of Adaptation in Film \& Performance 3:2 (2010): 157-170.

Raphael, Amy. “Love Will Tear Us Apart.” Sight \& Sound 21:12 (December 2011) 34-36.

Rogers, Jami. "The Shakespearean Glass Ceiling: the State of Colorblind Casting in Contemporary British Theatre.” Shakespeare Bulletin 31:3 (Fall 2013) 405-430.

Samuel, Raphael. ““Who Calls So Loud?’ Dickens on Stage and Screen,” Theatres of Memory: Past and Present in Contemporary Culture. London: Verso, 1994: 413-425. Samuel, Raphael. "Dockland Dickens." Theatres of Memory: Past and Present in Contemporary Culture. London: Verso, 1994: 401-411.

Taylor, Jenny Bourne. “'Received, a Blank Child': John Brownlow, Charles Dickens, and the London Foundling Hospital - Archives and Fictions." Nineteenth-Century Literature 56:3 (December 2001): 293-363.

The Mystery of Edwin Drood. Dir. Diarmuid Lawrence. BBC. 2013.

Thompson, Ayanna. "Practicing a Theory/ Theorizing a Practice: An Introduction to Shakespearean Colorblind Casting." Colorblind Shakespeare: New Perspectives on Race and Performance. Ed. Ayanna Thompson. New York; London: Routledge, 2006: $1-26$. 
Thompson, Ayanna. "To Notice or Not to Notice: Shakespeare, Black Actors and Performance Reviews." Borrowers and Lenders: The Journal of Shakespeare and Appropriation 4:1 (2008 Fall - 2009 Winter): 1-15.

Zemka, Sue. "The Death of Nancy 'Sikes', 1838-1912,” Representations. 110:1 (Spring 2010): 29-57. 